parable standards among the different accrediting agencies; the second is how to inform and win over the public so that they will choose accredited institutions and programs.

\section{Belize: A New University and a New Direction}

\section{Franklin D. Roberts}

Franklin D. Roberts is director of the Library and Media Center, University of Maine at Farmington, Farmington, ME 04938, USA. E-mail: <froberts@maine.edu>.

$\mathrm{O}$ n August 1, 2000, the University of Belize was born. UB was the product of a merger, initiated by the Ministry of Education, of five institutions-University College of Belize, Belmopan Junior College, Belize School of Nursing, Belize School of Education, and Belize College of Agriculture. A similar, unsuccessful, merger of higher education institutions was tried over 15 years earlier, with the development of the Belize College of Arts, Sciences, and Technology. At that time, there was much interinstitutional squabbling about who would administer and exercise control over the institution, and when the conservative United Democratic Party (UDP) came back into power, the institution was branded leftist (some said communist) and disbanded. Under the UDP, the University College of Belize (UCB) was developed loosely as a national university - in addition to the other publicly supported higher education institutions: an agricultural college (under the Ministry of Agriculture), a nursing school (under the Ministry of Health), and several junior colleges and a teacher's college (under the Ministry of Education). The new minister of education who came to power when the People's United Party (PUP) government was elected in 1998 felt that a consolidation of resources was necessary.

A less-developed small nation, Belize is located in Central America, just south of Mexico's Yucatan peninsula and east of Guatemala, with a population of some 240,000, including 30,000 new immigrants from the rest of Central America. The country is racially diverse: the largest population group (about 40 percent) is mestizos (Spanish/Indian), a recent shift due to the new immigrants; followed by the Creoles (African/European), about 30 percent, and formerly the largest group; the Garifunas (African/Caribe Indian), about 10 percent, the Maya Indian, about 6 percent; and various other groups (Chinese, East Indians, white Mennonites), and others, who emigrated when Belize was still the British colony of British Honduras.
Higher Education Policy

Belize's national higher education system (not including private institutions) has both suffered and benefited from benign neglect. Since 1990, the government has annually allotted $\$ 1$ million BZ (U.S. $\$ 500,000$ ) to higher education, with no increases and no stated goals for institutional development. In 1986, the UCB essentially became a branch campus of Ferris State University, in Michigan, but the country broke ties with that institution in 1990 after learning that Ferris did not have the authority to offer accredited programs in Belize. The UCB Act, which formed that institution, had a clause giving the minister of education power to "recommend" (read: direct) policies to the board of trustees, but after appeals by the faculty, this clause was rescinded. To the dismay of the academic community, the new University of Belize Act also has such a clause (clause 20), but the ministry has offered to proffer an amendment to nullify this clause. Aside from these actions, the government of Belize has largely allowed higher education to flourish or flounder on its own, which has permitted institutions a high degree of autonomy and to develop their arts and social sciences curriculum reasonably well. However, lack of financial support has caused teaching in the sciences and other fiscally intensive disciplines to suffer.

\section{International Connections}

Apart from the disappointing coupling with Ferris State University, Belize has benefited from some of its international connections, and UB plans to continue to build on these. The administrative offices of the university are housed in the Regional Language Center building, built by the government of Taiwan. Since the bulk of UB programs will be offered in Belmopan, the capital city, three new buildings (two for classrooms and one to house a gymnasium) will be built there with hurricane relief funds from the Carribean Development Bank (the buildings will act as shelters during the frequent hurricanes that hit the more heavily populated coastal regions). UB belongs to COBEC (Consortium of Belize Educational Cooperation) with 14 U.S. colleges and 4 others from Belize, which offers student and faculty exchanges and mutual research opportunities, among other things, to all members.

Since its independence from the United Kingdom in 1981, Belize has adopted a more U.S.-oriented higher education system, and most faculty pursuing advanced degrees go to U.S. institutions. UB is also a member of CSUCA (Consejo superior de universidades de Centro America), a 16-nation council of Central American tertiary education institutions (in fact, the president of UB is a recent past president of the council). CSUCA membership is good for Belize because the coun- 
try in the past was more aligned with the United States and the Carribean than with Central America and became estranged from many of the countries whose refugees found a home in Belize. But after the end of the Cold War, Belize ceased to be as important to the United States as a bastion of democracy (in a region with several leftist governments backed by the former Soviet Union). Furthermore, and internal movements called for Belizeans to take their place among their Central American neighbors (there has even been some discussion of adopting bilingualism nationally, given the heavy influx of Spanish-speaking peoples). CSUCA has legitimation and prestige with European institutions, allowing Belize to lessen its dependence on the largesse of the United States, especially since that generosity has lessened with Belize's diminished strategic importance.

\section{The Future of the University of Belize}

With the construction of new buildings and the physical relocation of the various academic faculties of UB to Belmopan, the institution shows promise of becoming a permanent fixture. The new university has a budget of about $\$ 10,000,000$ BZ (U.S.\$5 million) for its first year, with capital funds of $\$ 3,000,000 \mathrm{BZ}$, and about $\$ 11,000,000 \mathrm{BZ}$ for FY2001/2002. The major obstacle to retaining what is being developed is the history of Belizean politics. Since its independence 20 years ago, the PUP and the UDP have alternated power every five years. A new election is to be held in 2003. Administrators at UB have been working with leaders in the UDP (the PUP is currently in power), to try to ensure that the institution survives a change in government, if history is repeated and the opposition party is reelected.

The institution is working hard to include campus, community, and government in the change process, but it now needs to develop an institutional culture of its own. Recent steps include the hiring of a vice president of student affairs and a director of research. Barring political infighting by a future government, or interference in the internal workings of the institution by the minister of education, UB has a chance to grow into a major force for development in Belize.

\section{News of the Center and the Program in Higher Education}

The Center is beginning a new initiative on private higher education. In collaboration with Professor Dan Levy at the State University of New York at Albany and with the support of the Ford Foundation, current information and analysis on private higher education worldwide will be collected, categorized, and made available to a wide audience through publications and a website. Alma Maldonado, a doctoral candidate in the Center for International Higher Education, will be responsible for this new project in collaboration with a colleague at SUNY-Albany.

The Ford Foundation, which has supported the work of the Center for the past several years, has renewed its support for an additional two years. This support will permit the Center to publish its newsletter and develop further initiatives in international higher education.

A successful working conference on the changing academic workplace was held in May at the Rockefeller Foundation's conference center in Bellagio, Italy. The conference brought together scholars from 13 countries-including India, China, South Korea, South Africa, Argentina, Brazil, Russia, and others-who wrote essays on the academic profession. A book will be prepared based on these essays. The project is funded by the Ford Foundation and the Rockefeller Foundation.

A special theme issue of Higher Education: The International Fournal of Higher Education and Educational Planning concerning comparative perspectives on the academic workplace in Europe and North America has been published. It is coedited by Philip G. Altbach, Jürgen Enders of the University of Kassel in Germany, and Richard Chait of Harvard University. The issue features articles on eight countries. It is the January-March, 2001 issue.

Philip G. Altbach, director of the Center, continues to teach in the master's program in higher education at the Universidad de Palermo in Buenos Aires, Argentina. This program provides training to higher education professionals. Philip Altbach's book on comparative higher education will be published in Spanish in Argentina as part of the Palermo program. The program is directed by Professor Miguel Escotet, UNESCO Chair in higher education at Palermo. Philip Altbach will keynote a conference on general education at Tamagawa University in Tokyo, Japan in December.

In Defense of American Higher Education, edited by Philip G. Altbach, Patricia J. Gumport, and D. Bruce Johnstone, has been published by the Johns Hopkins University Press. It is available in both paperback and hardcover editions. The book features essays providing a critical yet positive analysis of contemporary American higher education. 